
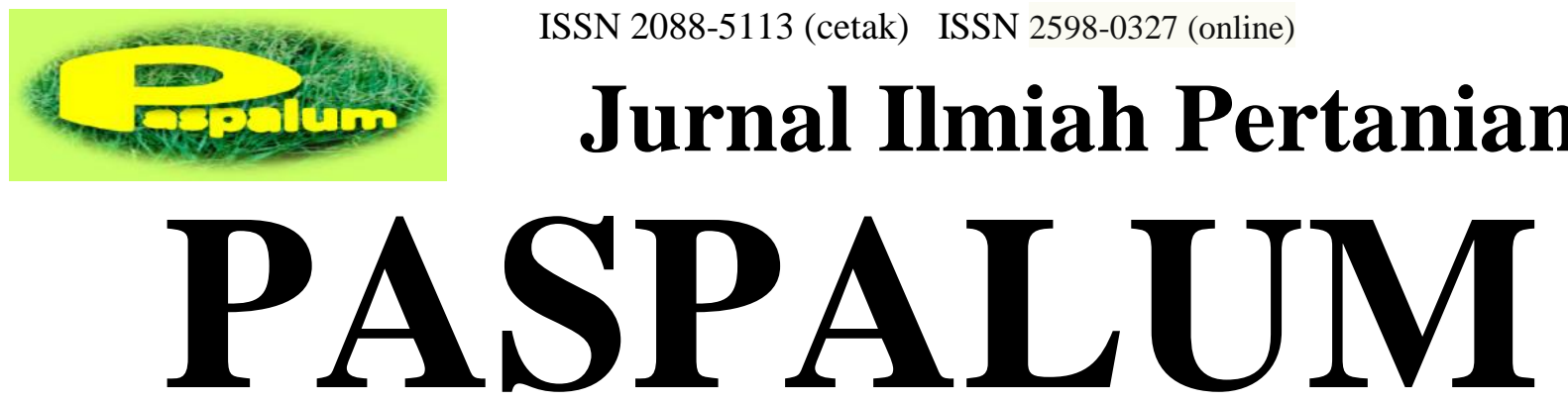

Volume. 6 No. 1 Bulan Maret Tahun 2018

http://journal.unwim.ac.id/index.php/paspalum

\title{
Pengaruh Pupuk Kompos Kulit Buah Kakao Dan Pupuk Tablet Terhadap Produksi Kakao (Theobroma cacao L.)
}

\author{
Muhamad Eza Suprapto, Santi Rosniawaty dan Mira Ariyanti \\ Program Studi Agroteknologi Fakultas Pertanian Unpad \\ santi.rosniawaty@unpad.ac.id
}

Diterima tgl : 22-02-2018 dan disetujui untuk diterbitkan tgl : 31-03-2018

\begin{abstract}
Cocoa is one of the estate crop whose role is quite important for the national economy, particularly as a provider of employment, income and foreign exchange. The high export opportunities of cocoa beans has not been followed by the production of cocoa beans in Indonesian. The production of dried cacao beans in Indonesia is still low. The low productivity of seeds generally caused by Cherelle wilt of cacao. Wilting occurs due to inability of the cherelle to compete with the other cherelle in absorbing nutrients. Fertilization is an effort to maintain and fulfill the nutrients in the plants. This research is aimed to assess the effect of fertilization using cocoa pod husk and NPK tablets fertilization on cocoa crop yields. This experiment was conducted at PT. PP. Bajabang Indonesia, Cipeundeuy, West Bandung regency from December 2016 to March 2017. The experiment was conducted using a Simple Randomized Block Design that consists 10 treatments: control, single N, P, K fertilizer $297 \mathrm{~g} /$ tree, cocoa pod husk $9 \mathrm{~kg} /$ tree, cocoa pod husk $9 \mathrm{~kg} /$ tree + single $\mathrm{N}, \mathrm{P}, \mathrm{K}$ fertilizer $297 \mathrm{~g} /$ tree, cocoa pod husk $18 \mathrm{~kg} /$ tree + single N, P, K fertilizer $297 \mathrm{~g} /$ tree, cocoa pod husk $9 \mathrm{~kg} /$ tree + NPK tablet fertilizer 20 tablets/tree, NPK tablet fertilizer 20 tablets/tree, cocoa pod husk $9 \mathrm{~kg} /$ tree + NPK tablet fertilizer 10 tablets/tree, cocoa pod husk $18 \mathrm{~kg} /$ tree + NPK tablet fertilizer 20 tablets/ tree, cocoa pod husk $18 \mathrm{~kg} /$ tree + NPK tablet fertilizer 10 tablets/tree. The result of experiment showed that there was an influence of cocoa pod husk and NPK tablet fertilizer on cocoa fruit weight at $12 \mathrm{MSP}$, that is cocoa pod husk $9 \mathrm{~kg} / \mathrm{tree}+\mathrm{NPK}$ tablet fertilizer 20 tablets/tree. Number of cherelle wilted at $12 \mathrm{MSP}$ with cocoa pod husk $9 \mathrm{~kg} / \mathrm{tree}+\mathrm{NPK}$ tablet fertilizer 20 tablets/tree.
\end{abstract}

Keywords: cocoa, Single NPK, NPK tablets, cocoa pod husk.

Abstrak

Kakao merupakan salah satu komoditas andalan perkebunan yang peranannya cukup penting bagi perekonomian nasional, khususnya sebagai penyedia lapangan kerja, sumber pendapatan dan devisa negara. Peluang ekspor biji kakao yang tinggi belum diikuti oleh produksi biji kakao Indonesia. Produksi biji kering kakao di Indonesia masih tergolong rendah. Rendahnya produktivitas biji salah satunya disebabkan oleh layu pentil kakao. Layu pentil terjadi akibat ketidakmampuan pentil untuk bersaing dengan pentil lain dalam menyerap nutrisi. Pemupukan merupakan upaya pemeliharaan agar nutrsi yang dibutuhkan dalam tanaman tercukupi. Penelitian ini bertujuan untuk mengkaji pengaruh pemupukan dengan kompos kulit buah kakao (KKBK) dan pemupukan NPK tablet terhadap hasil tanaman kakao. Percobaan ini dilaksanakan di PT. PP. Bajabang Indonesia, Cipeundeuy, Kabupaten Bandung Barat dari bulan Desember 2016 sampai Maret 2017. Percobaan dilakukan menggunakan Rancangan Acak Kelompok dengan sepuluh perlakuan yaitu kontrol, Pupuk urea 137 g SP-36 23 g dan KCl 137 g, KKBK 9 kg, KKBK 9 kg + pupuk urea 137 g SP-36 23 g dan KCl 137 g, KKBK $18 \mathrm{~kg}$ + pupuk urea $137 \mathrm{~g} \mathrm{SP-36} 23 \mathrm{~g}$ dan KCl $137 \mathrm{~g}$, KKBK $9 \mathrm{~kg}+$ pupuk NPK tablet 20 butir, Tanpa 
KKBK+ pupuk NPK tablet 20 butir, KKBK $9 \mathrm{~kg}+$ pupuk NPK tablet 10 butir, KKBK $18 \mathrm{~kg}+$ pupuk NPK tablet 20 butir, KKBK $18 \mathrm{~kg}$ + pupuk NPK tablet 10 butir. Hasil percobaan menunjukkan terdapat pengaruh pupuk kompos kulit buah kakao dan pupuk NPK tablet terhadap Jumlah pentil layu pada 12 MSP dengan pemberian KKBK 9kg + pupuk NPK tablet 20 butir dan KKBK $18 \mathrm{~kg}$ + pupuk NPK tablet 10 butir. Bobot buah kakao pada 12 MSP dengan pemberian KKBK $9 \mathrm{~kg}+$ pupuk NPK tablet 20 butir dan KKBK $18 \mathrm{~kg}+$ pupuk NPK tablet 10 butir.

Kata kunci: kakao, kompos kulit buah kakao, NPK tablet, NPK tunggal

\section{PENDAHULUAN}

Kakao (Theobroma cacao L.) termasuk salah satu komoditas perkebunan yang dikembangkan untuk kepentingan ekspor dan untuk memenuhi kebutuhan industri makanan dan minuman dalam negeri. Kakao juga merupakan salah satu komoditas andalan perkebunan yang peranannya cukup penting bagi perekonomian nasional, khususnya sebagai penyedia lapangan kerja, sumber pendapatan dan devisa negara. Hal ini dapat dilihat dari pertumbuhan laju nilai ekspor yang mencapai $10 \%$ per tahun (Direktorat Jenderal Perkebunan, 2010).

Volume nilai ekspor kakao Indonesia selama rentang waktu lima tahun mengalami fluktuatif, dimana nilai ekspor kakao yang pada tahun 2009 sebesar 1.413.500 US\$, lalu pada tahun 2010 meningkat menjadi 1.643 .700 US\$ dan menurun drastis pada tahun 2011 dan 2012 yang masing-masing menghasilkan 1.172.000 US\$ dan 1.053.500 US\$. Pada tahun 2013 meningkat menjadi 1.151 .500 US\$ (Direktorat Jendral Perkebunan, 2014). Berdasarkan volume ekspor dan nilai ekspor pada tahun 2013 mendorong Indonesia menjadi produsen kakao terbesar kedua setelah Pantai Gading (Food Association Organization, 2014).

Peluang ekspor biji kakao yang tinggi belum diikuti oleh produksi biji kakao Indonesia. Produksi biji kering kakao di Indonesia masih tergolong rendah, yaitu ratarata $897 \mathrm{~kg} \mathrm{ha}^{-1}$ per tahun. Hal ini sangat berbanding terbalik dengan potensi yang bisa mencapai $2.000 \mathrm{~kg} \mathrm{ha}^{-1}$ per tahun (Bidang
Pasca Panen dan Sistem Informasi Dinas Perkebunan Sulawesi, 2010). Rendahnya produktivitas tanaman kakao di Indonesia disebabkan beberapa faktor seperti, penggunaan bahan tanaman yang kurang optimal, pembuahan yang tidak optimal, umur tanaman, serangan hama dan penyakit, serta teknologi budidaya yang digunakan kurang baik (Wahyudi dkk., 2008).

Peningkatan produktivitas kakao dapat dilakukan dengan pengoptimalan proses pembuahan pada budidaya kakao (Tanaman Menghasilkan). Permasalahan yang selama ini dijumpai pada pembuahan kakao adalah layu pentil (Cherelle wilt) (Hartati dkk., 2007). Layu pentil kakao dapat dipandang sebagai penyakit fisiologis yang harkatnya dapat mencapai $60-90 \%$, dan hal ini ternyata terkait dengan sifat genetik kakao. Gejala ini menurut Urquhart (1961) dan Prawoto (2000) dalam Erwiyono (2006), dinilai merupakan proses pembatasan fisiologis yang disebabkan oleh persaingan nutrisi dan air di antara bagianbagian tanaman yang sedang tumbuh aktif, yaitu bunga, buah dan tunas baru (flush). Hutcheon (1976) dalam Erwiyono (2006), membuktikan bahwa karbohidrat sebagai faktor penting dalam pembungaan, sehingga praktek-praktek yang mendukung fotosintesis juga akan mendukung pembungaan, serta adanya kompetitor pemakai karbohidrat seperti buah, berpeluang menunda pembungaan. Pemupukan merupakan salah satu cara untuk mendukung proses fotosintesis pada tanaman.

Pupuk anorganik adalah salah satu cara untuk memenuhi kebutuhan unsur hara untuk tanaman kakao. Penggunanan pupuk NPK 
tablet dapat menjadi solusi dan alternatif dalam meningkatkan produktivitas tanaman kakao. Penggunaan pupuk NPK tablet diharapkan dapat memberikan kemudahan dalam pengaplikasian di lapangan dan dapat meningkatkan kandungan unsur hara yang dibutuhkan di dalam tanah serta dapat dimanfaatkan langsung oleh tanaman. Hal ini sejalan dengan pendapat Sutejo (2002), bahwa pemberian pupuk anorganik ke dalam tanah dapat menambah ketersediaan hara yang cepat bagi tanaman. Pupuk NPK tablet yang akan digunakan dalam penelitian ini adalah pupuk yang dibuat dengan mencampurkan unsurunsur pupuk yaitu N, P dan K. Pupuk ini mengandung hara utama dengan komposisi $15 \%$ nitrogen, $10 \%$ fosfor dan $18 \%$ kalium serta unsur hara mikro yang tidak ada dalam pupuk tunggal. Pupuk tablet merupakan pupuk majemuk lengkap yang dapat membantu menyediakan unsur hara untuk tanaman kakao. Berdasarkan sifat kimianya, tanaman kakao membutuhkan tanah yang memiliki kaya akan bahan-bahan organik (Bidang Pasca Panen dan Sistem Informasi Dinas Perkebunan Sulawesi, 2010). Berdasarkan hasil analisis tanah awal, Kampung Pasir Ucing-Cibungur memiliki jenis tanah Inceptisol dengan kandungan bahan organik yang rendah yaitu sebesar 1,03\% sedangkan menurut Wahyudi dkk., (2008), tanaman kakao membutuhkan tanah yang memiliki kandungan bahan organik lebih dari 4\%. Menurut Hidayat dan Mulyani (2005) dalam Nurdin (2012), tanah-tanah pada lahan kering umumnya termasuk ordo Ultisol, Oxisol dan Inceptisol. Umumnya lahan kering memiliki tingkat kesuburan tanah yang rendah, dan kadar bahan organik rendah (Abdurachman dkk., 2008). Pemberian pupuk organik pada tanah dapat membantu perbaikan sifat fisik, kimia dan biologi tanah (Sutanto, 2002). Kompos kulit buah kakao dapat memperbaiki $\mathrm{pH}$ tanah dan C-organik (Sudirja dkk., 2005). Berdasarkan uraian tersebut, maka diharapkan pemupukan kompos kulit buah kakao dan pupuk tablet dapat berpengaruh pada produksi tanaman kakao menghasilkan.

\section{BAHAN DAN METODE}

Percobaan dilaksanakan di lahan perkebunan kakao milik PT. PP. Bajabang Indonesia yang terletak di Kampung Pasir Ucing - Cibungur, Desa Naggeleng, Kecamatan Cipeundeuy, Kabupaten Bandung Barat, Provinsi Jawa Barat dengan ketinggian $212 \mathrm{~m}$ di atas permukaan laut dengan curah hujan rata-rata $2500 \mathrm{~mm} /$ tahun dengan tipe iklim C berdasarkan Schmidt-Ferguson (1951). Ordo tanah di lokasi percobaan adalah Inceptisol. Percobaan dilakukan mulai bulan Desember 2016 sampai dengan Maret 2017. Rancangan percobaan yang digunakan adalah Rancangan Acak Kelompok. Terdapat sepuluh perlakuan. Setiap perlakuan diulang sebanyak tiga kali sehingga terdapat 30 satuan percobaan, dengan satu tanaman contoh di setiap satuan percobaan sehingga tanaman yang diperlukan seluruhnya berjumlah 30 tanaman.

Perlakuan yang dilakukan adalah :

A : Kontrol

B : Pupuk urea $137 \mathrm{~g}$, SP-36 $23 \mathrm{~g}$, dan $\mathrm{KCl}$ 137 g 297 gram.

C : Kompos kulit buah kakao $9 \mathrm{~kg}$

D : Kompos kulit buah kakao $9 \mathrm{~kg}+$ Pupuk urea 137 g, SP-36 $23 \mathrm{~g}$, dan $\mathrm{KCl} 137 \mathrm{~g}$

E : Kompos kulit buah kakao $18 \mathrm{~kg}+$ pupuk urea 137 g, SP-36 $23 \mathrm{~g}$, dan KCl $137 \mathrm{~g}$

F : Kompos kulit buah kakao $9 \mathrm{~kg}+$ pupuk NPK tablet20 butir@10g

$\mathrm{G}$ : Kompos kulit buah kakao $9 \mathrm{~kg}+$ pupuk NPK tablet 20 butir @ $10 \mathrm{~g}$

$\mathrm{H}$ : Kompos kulit buah kakao $9 \mathrm{~kg}+$ pupuk NPK tablet 10 butir@10g

I : Kompos kulit buah kakao $18 \mathrm{~kg}+$ pupuk NPK tablet 20 butir @ $10 \mathrm{~g}$

$\mathrm{J}$ : Kompos kulit buah kakao $18 \mathrm{~kg}+$ pupuk NPK tablet 10 butir@10 g 


\section{HASIL DAN PEMBAHASAN}

Jumlah Pentil Kakao Terbentuk. Jumlah pentil kakao terbentuk merupakan salah satu parameter dalam penelitian ini. Kategori pentil kakao terbentuk yaitu pentil yang berukuran 1$5 \mathrm{~cm}$. Hasil sidik ragam menunjukan bahwa pemberian kompos kulit buah kakao dan pupuk NPK tablet tidak berpengaruh nyata terhadap jumlah pentil kakao terbentuk selama 0 MSP sampai 12 MSP. Data jumlah pentil kakao terbentuk selama percobaan dapat dilihat pada Tabel 1.
Perlakuan pemberian kompos kulit buah kakao dan pupuk NPK tablet tidak memberikan pengaruh nyata. Hal ini diduga akibat dari pemberian perangsang tumbuh lainnya sebagai usaha pemeliharaan oleh perusahaan. Aplikasi perangsang tumbuh lainnya diberikan pada saat 3 MSP dan 4 MSP. Pemberian bahan-bahan ini menyebabkan pemberian kompos kulit buah kakao dan pupuk NPK tablet tidak terlihat secara nyata sehinga tanaman kakao tidak responsif.

Tabel 1. Pengaruh Kompos Kulit Buah Kakao dan Pupuk NPK Tablet terhadap Jumlah Pentil Kakao Terbentuk (Pentil/Pohon) pada 0 sampai 12 MSP

\begin{tabular}{cccccccc}
\hline & \multicolumn{7}{c}{ Waktu Pengamatan (MSP) } \\
Perlakuan & $\mathbf{0}$ & $\mathbf{2}$ & $\mathbf{4}$ & $\mathbf{6}$ & $\mathbf{8}$ & $\mathbf{1 0}$ & $\mathbf{1 2}$ \\
\hline $\mathbf{A}$ & 0,67 & 0,67 & 1,33 & 2,00 & 2,00 & 3,00 & 3,00 \\
$\mathbf{B}$ & 2,00 & 2,67 & 2,67 & 3,00 & 3,33 & 4,33 & 4,67 \\
$\mathbf{C}$ & 0,67 & 0,67 & 1,00 & 2,00 & 2,00 & 3,00 & 3,33 \\
$\mathbf{D}$ & 0,67 & 1,00 & 1,00 & 2,33 & 2,33 & 4,00 & 5,67 \\
$\mathbf{E}$ & 2,33 & 2,67 & 3,00 & 3,33 & 3,67 & 5,00 & 6,67 \\
$\mathbf{F}$ & 3,00 & 3,33 & 4,00 & 4,67 & 4,67 & 7,00 & 9,33 \\
$\mathbf{G}$ & 1,33 & 2,00 & 2,00 & 2,00 & 4,00 & 4,00 & 4,33 \\
$\mathbf{H}$ & 2,67 & 3,67 & 4,33 & 4,33 & 4,33 & 4,67 & 5,67 \\
$\mathbf{I}$ & 0,67 & 1,00 & 4,00 & 4,00 & 4,33 & 6,00 & 7,33 \\
$\mathbf{J}$ & 4,33 & 6,00 & 6,67 & 6,67 & 6,67 & 7,33 & 7,67 \\
\hline
\end{tabular}

Keterangan : -Angka yang tidak ditandai dengan huruf menyatakan tidak berbeda nyata menurut Uji $\mathrm{F}$ pada taraf kepercayaan $95 \%$.

Walaupun secara statistik pemberian kompos kulit buah kakao tidak berpengaruh nyata namun pada Tabel 1 menunjukkan trend perlakuan pemberian kompos kulit buah kakao $9 \mathrm{~kg}+$ pupuk NPK tablet 20 butir cenderung mampu meningkatkan jumlah pentil kakao terbentuk. Jumlah pentil kakao terbentuk erat kaitannya dengan jumlah bunga yang dihasilkan dan banyaknya bunga yang mengalami penyerbukan dan pembuahan (Darjanto dan Satifah, 1982). Salah satu unsur pupuk yang dinilai paling relevan untuk menekan kerontokan bunga adalah kalium (Erwiyono dkk., 2006). Pada perlakuan pemberian kompos $9 \mathrm{~kg}+$ pupuk NPK tablet 20 butir dapat meningkatan $\mathrm{K}$-dd di dalam tanah. Hasil analis tanah awal K-dd 0,16 cmol.kg-1 meningkat menjadi $0,66 \mathrm{cmol} . \mathrm{kg}^{-1}$.

Jumlah Pentil Kakao Layu. Hasil analisis ragam menunjukkan bahwa pemberian kompos kulit buah kakao dan pemberian pupuk NPK tablet tidak berpengaruh nyata pada 0 MSP sampai 10 MSP. Pemberian 
45 I Paspalum: Jurnal IImiah Pertanian Vol.6, No.1, Maret 2018

kompos kulit buah kakao baru terlihat berpengaruh nyata pada 12 MSP. Data jumlah pentil kakao layu selama percobaan dapat dilihat pada Tabel 2.

Pada Tabel 2 menunjukkan bahwa pada perlakuan pemberian kompos kulit buah kakao $9 \mathrm{~kg}+$ pupuk NPK tablet 20 butir dan perlakuan pemberian kompos kulit buah kakao $18 \mathrm{~kg}+$ pupuk NPK tablet 10 butir menunjukkan presentase jumlah pentil layu kakao paling kecil. Hal ini menunjukkan pemberian kompos kulit buah kakao dan pupuk NPK tablet membantu menyuplai kebutuhan unsur hara yang dibutuhkan tanaman kakao.

Pada perlakuan pemberian kompos kulit buah kakao $9 \mathrm{~kg}+$ pupuk NPK tablet 20 butir dan perlakuan pemberian kulit kompos buah kakao $18 \mathrm{~kg}+$ pupuk NPK tablet 10 butir ketersedian unsur $\mathrm{K}$ termasuk kategori tinggi yaitu $0,66 \mathrm{cmol} . \mathrm{kg}^{-1}$ dan $0,56 \mathrm{cmol} . \mathrm{kg}^{-1}$.
Kalium merupakan unsur yang paling relevan untuk menekan kerontokan bunga dan faktor penting terjadinya cherelle wilt. Selain itu, pemberian bahan organik juga dapat meningkatkan KTK tanah (Santoso et al., 2003; Baon dan Wibawa, 2005) sehingga meningkatkan retensi unsur hara melalui peningkatan muatan di dalam tanah akibatnya bertambahnya muatan negatif (Stevenson, 1994).

Lebih lanjut Stevenson (1994) menyatakan bahwa bahan organik akan membentuk senyawa kompleks yang stabil dengan $\mathrm{Cu}^{2+}, \mathrm{Mn}^{2+}, \mathrm{Fe}^{2+}$ dan $\mathrm{Zn}^{2+}$ maupun kation polivalen lainnya akibatnya ketersediaan unsur-unsur tersebut meningkat. Pada tanaman kakao Zn mempunyai peranan penting dalam menurunkan layu pentil (Widiancas, 2010).

Tabel 2. Pengaruh Kompos Kulit Buah Kakao dan Pupuk NPK Tablet terhadap Jumlah Pentil Kakao Layu (Pentil/Pohon) pada 0 sampai 10 MSP

\begin{tabular}{cccccccc}
\hline & \multicolumn{7}{c}{ Waktu Pengamatan (MSP) } \\
Perlakuan & $\mathbf{0}$ & $\mathbf{2}$ & $\mathbf{4}$ & $\mathbf{6}$ & $\mathbf{8}$ & $\mathbf{1 0}$ & $\mathbf{1 2}$ \\
\hline $\mathbf{A}$ & 5,33 & 5,33 & 5,33 & 6,00 & 9,00 & 17,67 & $31,33 \mathrm{~b}$ \\
$\mathbf{B}$ & 3,00 & 3,67 & 4,67 & 5,00 & 7,00 & 10,33 & $24,33 \mathrm{ab}$ \\
$\mathbf{C}$ & 3,00 & 3,33 & 3,33 & 4,00 & 5,00 & 14,67 & $29,33 \mathrm{~b}$ \\
$\mathbf{D}$ & 5,33 & 5,33 & 5,33 & 5,67 & 7,67 & 13,67 & $24,00 \mathrm{ab}$ \\
$\mathbf{E}$ & 4,33 & 5,33 & 5,67 & 6,00 & 9,00 & 12,33 & $23,33 \mathrm{ab}$ \\
$\mathbf{F}$ & 3,33 & 3,33 & 4,00 & 4,67 & 5,67 & 12,67 & $18,00 \mathrm{a}$ \\
$\mathbf{G}$ & 5,67 & 5,67 & 6,33 & 6,33 & 9,33 & 14,33 & $24,33 \mathrm{ab}$ \\
$\mathbf{H}$ & 2,67 & 4,33 & 4,33 & 4,33 & 5,33 & 18,67 & $26,00 \mathrm{ab}$ \\
$\mathbf{I}$ & 3,33 & 3,33 & 3,33 & 4,00 & 5,00 & 18,33 & $25,00 \mathrm{ab}$ \\
J & 6,33 & 6,67 & 6,67 & 6,67 & 9,67 & 18,33 & $19,67 \mathrm{a}$ \\
\hline
\end{tabular}

Keterangan : -Angka yang tidak ditandai dengan huruf menyatakan tidak berbeda nyata menurut Uji F pada taraf kepercayaan $95 \%$.

Jumlah Pentil Kakao Sehat. Jumlah pentil kakao sehat merupakan salah satu parameter dalam penelitian ini. Kategori pentil kakao sehat yaitu pentil yang berukuran $5-11 \mathrm{~cm}$. Pentil berwarna hijau dan tidak terdapat gejala yang menunjukkan terserang hama dan penyakit. Hasil sidik ragam menunjukan bahwa pemberian kompos kulit buah kakao dan pupuk NPK tablet tidak berpengaruh nyata terhadap jumlah pentil kakao sehat selama 0 MSP sampai 12 MSP. Data jumlah pentil kakao selama percobaan dapat dilihat pada Tabel 3.

Perlakuan pemberian kompos kulit buah kakao dan pupuk NPK tablet tidak memberikan pengaruh nyata. Hal ini diduga 
46 I Paspalum: Jurnal IImiah Pertanian Vol.6, No.1, Maret 2018

akibat curah hujan yang tinggi selama percobaan. Curah hujan yang terlalu tinggi ini mengakibatkan kakao terserang penyakit busuk buah yang disebabkan Phytoptora palmivora (Karmawati dkk., 2010). Serangan penyakit ini pada lahan percobaan termasuk dalam kategori tinggi mencapai 30\% dengan gejala pembusukan disertai bercak coklat kehitaman. Meningkatnya serangan penyakit busuk buah ini mengakibatkan tingginya pentil yang layu selama percobaan sehingga pemberian kompos kulit buah kakao dan pupuk NPK tablet tidak berpengaruh terhadap jumlah pentil kakao sehat.

Jumlah Buah Kakao. Hasil sidik ragam menunjukkan bahwa pemberian kompos kulit buah kakao dan pupuk NPK tablet tidak berpengaruh nyata terhadap jumlah buah kakao selama 0 MSP sampai 12 MSP. Data jumlah buah kakao selama percobaan dapat dilihat pada Tabel 4.

Tabel 4 menunjukkan bahwa terjadi penurunan jumlah buah kakao pada 12 MSP hal ini dikarenakan buah yang masak telah dipanen. Peningkatan jumlah buah kakao baru terlihat pada 10 MSP. Hal ini diduga disebabkan ketersediaan unsur hara bagi tanaman pada pemberian kompos kulit buah kakao karena kompos kulit buah kakao membutuhkan waktu yang cukup lama dalam membentuk ion larutan unsur hara yang dapat diserap oleh akar tanaman. Selain itu pupuk NPK tablet merupakan pupuk yang bersifat (slow release) karena NPK tablet berbentuk padat sehingga diperlukan proses penghancuran terhadap fisik pupuk di dalam tanah agar dapat dimanfaatkan oleh tanaman (Rakasiwi dkk., 2014).

Tabel 3. Pengaruh Kompos Kulit Buah Kakao dan Pupuk NPK Tablet terhadap Jumlah Pentil Kakao Sehat (Pentil/Pohon) pada 0 sampai 12 MSP

\begin{tabular}{cccccccc}
\hline \multirow{2}{*}{ Perlakuan } & $\mathbf{0}$ & $\mathbf{9}$ Waktu Pengamatan (MSP) \\
& $\mathbf{0}$ & $\mathbf{2}$ & $\mathbf{4}$ & $\mathbf{6}$ & $\mathbf{8}$ & $\mathbf{1 0}$ & $\mathbf{1 2}$ \\
\hline $\mathbf{A}$ & 3,00 & 3,33 & 4,00 & 4,33 & 5,67 & 6,00 & 9,00 \\
$\mathbf{B}$ & 2,67 & 3,33 & 3,67 & 4,00 & 5,33 & 7,67 & 10,00 \\
$\mathbf{C}$ & 8,33 & 9,00 & 9,67 & 9,67 & 10,33 & 10,33 & 10,33 \\
$\mathbf{D}$ & 3,33 & 3,67 & 6,00 & 6,33 & 7,33 & 8,67 & 11,33 \\
$\mathbf{E}$ & 4,00 & 4,33 & 5,33 & 6,67 & 8,33 & 9,33 & 11,33 \\
$\mathbf{F}$ & 7,67 & 8,33 & 10,00 & 10,67 & 11,00 & 11,67 & 15,00 \\
$\mathbf{G}$ & 5,00 & 5,67 & 6,33 & 7,67 & 8,67 & 9,33 & 11,67 \\
$\mathbf{H}$ & 3,67 & 4,67 & 6,67 & 8,67 & 9,33 & 10,67 & 12,67 \\
$\mathbf{I}$ & 4,33 & 4,67 & 6,00 & 8,67 & 9,00 & 10,67 & 12,67 \\
$\mathbf{J}$ & 6,00 & 6,00 & 6,67 & 8,00 & 10,33 & 12,67 & 13,67 \\
\hline
\end{tabular}

Keterangan :-Hasil Transformasi Arcsin yang angkanya telah dikembalikan ke data awal -Angka yang tidak ditandai dengan huruf menyatakan tidak berbeda nyata menurut Uji F pada taraf kepercayaan $95 \%$. 
47 I Paspalum: Jurnal IImiah Pertanian Vol.6, No.1, Maret 2018

Tabel 4. Pengaruh Kompos Kulit Buah Kakao dan Pupuk NPK Tablet terhadap Jumlah Buah Kakao (Buah/Pohon) pada 0 sampai 12 MSP

\begin{tabular}{cccccccc}
\hline \multirow{2}{*}{ Perlakuan } & $\mathbf{0}$ & $\mathbf{9}$ & $\mathbf{4}$ & $\mathbf{6}$ & $\mathbf{8}$ & $\mathbf{1 0}$ & $\mathbf{1 2}$ \\
\hline $\mathbf{A}$ & 14,00 & 14,00 & 14,00 & 14,00 & 14,00 & 14,33 & 12,00 \\
$\mathbf{B}$ & 12,00 & 12,00 & 12,00 & 12,00 & 12,00 & 12,67 & 11,00 \\
$\mathbf{C}$ & 15,67 & 15,67 & 15,67 & 15,67 & 15,67 & 16,00 & 13,67 \\
$\mathbf{D}$ & 14,67 & 14,67 & 14,67 & 14,67 & 14,67 & 15,33 & 13,00 \\
$\mathbf{E}$ & 14,33 & 14,33 & 14,33 & 14,33 & 14,33 & 15,00 & 13,00 \\
$\mathbf{F}$ & 34,33 & 34,33 & 34,33 & 34,33 & 34,33 & 35,00 & 26,33 \\
$\mathbf{G}$ & 14,00 & 14,00 & 14,00 & 14,00 & 14,00 & 15,00 & 12,33 \\
$\mathbf{H}$ & 21,67 & 21,67 & 21,67 & 21,67 & 21,67 & 22,67 & 18,33 \\
$\mathbf{I}$ & 13,67 & 13,67 & 13,67 & 13,67 & 13,67 & 14,33 & 11,67 \\
$\mathbf{J}$ & 24,00 & 24,00 & 24,00 & 24,00 & 24,00 & 24,33 & 17,00 \\
\hline
\end{tabular}

Keterangan : - Hasil Transformasi Arcsin yang angkanya telah dikembalikan ke data awal

-Angka yang tidak ditandai dengan huruf menyatakan tidak berbeda nyata menurut Uji $F$ pada taraf kepercayaan $95 \%$.

Pemberian kompos kulit buah kakao dan pupuk NPK tablet tidak memberikan pengaruh nyata terhadap jumlah buah kakao. Hal ini diduga akibat dari pemberian perangsang bunga sebagai usaha pemeliharaan oleh perusahaan pada 6 MSP. Hal ini terbukti pada saat tanaman tidak berbuah, pembungaan meningkat. Sebaliknya, pada saat tanaman berbuah lebat, pembungaan sangat berkurang (Tjasadiharja, 1980 dalam Pusat Penelitian Kopi dan Kakao, 2010).

Bobot Buah Kakao. Hasil analisis sidik ragam menunjukkan bahwa pemberian kompos kulit buah kakao dan pupuk NPK tablet berpengaruh nyata terhadap bobot buah kakao. Data bobot buah kakao disajikan dalam Tabel 5. Pada Tabel 5 menunjukan bahwa bobot buah kakao tertinggi dihasilkan oleh perlakuan pemberian kompos kulit buah kakao $9 \mathrm{~kg}+$ pupuk NPK tablet 20 butir dan perlakuan pemberian kompos kulit buah kakao $18 \mathrm{~kg}+$ pupuk NPK tablet 10 butir.

Tingginya bobot buah kakao disebabkan oleh proses penyerapan unsur hara yang berjalan dengan baik. Sifat kimia yang diberikan dengan adanya kompos kulit buah kakao yaitu meningkatkan kapasitas tukar kation (KTK) dan C-organik serta mampu memperbaiki $\mathrm{pH}$ media tanam (Wahyudi, 2010). Adanya KTK yang tinggi di dalam tanah mempengaruhi daya jerap kation yang lebih tinggi pada media tanam. Hal ini akan mempengaruhi penyerapan hara yang sebelumnya terfiksasi menjadi hara yang dapat diserap dan dimanfaatkan oleh tanaman.

Pupuk NPK tablet juga menyediakan unsur-unsur makro yang dibutuhkan untuk pertumbuhan buah sampai masak. Kalium merupakan salah satu unsur yang sangat penting pada tanaman kakao karena unsur ini paling banyak ditransfer ke buah dan menjadi katalisator dalam setiap proses biokimia (Erwiyono dkk., 2006). Kalium dapat memperlancar pengangkutan karbohidrat dan mempengaruhi pertumbuhan buah sampai buah masak. Adanya kalium menyebabkan buah menjadi lebih kuat dan kualitasnya bertambah baik (Darjanto dan Satifah, 1982). 
48 I Paspalum: Jurnal IImiah Pertanian Vol.6, No.1, Maret

2018

Tabel 5. Pengaruh Kompos Kulit Buah Kakao dan Pupuk NPK Tablet terhadap Bobot Buah Kakao (Gram/Buah) pada Umur 12 MSP

\begin{tabular}{|c|c|}
\hline \multirow[b]{2}{*}{ Perlakuan } & Waktu Pengamatan (MSP) \\
\hline & 12 MSP \\
\hline A : Kontrol & $341,67 \mathrm{a}$ \\
\hline B : Pupuk urea $137 \mathrm{~g}, \mathrm{SP}-3623 \mathrm{~g}$, dan $\mathrm{KCl} \mathrm{137g}$ & $383,33 \mathrm{ab}$ \\
\hline $\mathrm{C}: \mathrm{KKBK} 9 \mathrm{~kg}$ & $341,67 \mathrm{a}$ \\
\hline D : KKBK $9 \mathrm{~kg}$ + Pupuk urea $137 \mathrm{~g}, \mathrm{SP}-3623 \mathrm{~g}$, dan $\mathrm{KCl}$ & \\
\hline $137 \mathrm{~g}$ & $416,67 \mathrm{ab}$ \\
\hline $\mathbf{E}:$ KKBK $18 \mathrm{~kg}+$ Pupuk urea $137 \mathrm{~g}$, SP-36 23g, dan $\mathrm{KCl}$ & \\
\hline $137 \mathrm{~g}$ & 308,33 a \\
\hline F : KKBK $9 \mathrm{~kg}+$ Pupuk NPK tablet 20 butir & $500,00 \mathrm{~b}$ \\
\hline G : Pupuk NPK tablet 20 butir & $392,00 \mathrm{ab}$ \\
\hline H : KKBK 9 kg + Pupuk NPK tablet 10 butir & $350,00 \mathrm{ab}$ \\
\hline I : KKBK $18 \mathrm{~kg}+$ Pupuk NPK tablet 20 butir & $475,00 \mathrm{ab}$ \\
\hline J : KKBK $18 \mathrm{~kg}+$ Pupuk NPK tablet 10 butir & $498,33 \mathrm{~b}$ \\
\hline
\end{tabular}

Keterangan : -Angka yang tidak ditandai dengan huruf menyatakan tidak berbeda nyata menurut Uji F pada taraf kepercayaan $95 \%$.

Pemberian kompos kulit buah kakao 9 $\mathrm{kg}+$ pupuk NPK tablet 20 butir ketersedian unsur $\mathrm{P}$ tergolong tinggi yaitu 30,05 ppm dan pemberian kompos kulit buah kakao $18 \mathrm{~kg}+$ pupuk NPK tablet 10 butir ketersedian unsur $\mathrm{P}$ tergolong sedang yaitu 18,36 ppm. Kecukupan unsur $\mathrm{P}$ dalam tanah dapat merangsang terbentuknya bulu akar dan akar rambut dan akibatnya serapan hara tanaman melalui akar meningkat (Hardjono, 1988 dalam Sugiyanto dkk, 2008). Hal ini menunjukkan bahwa pemberian kompos kulit buah kakao dan pupuk NPK tablet dapat meningkatkan bobot buah kakao.

Bobot Basah Biji dan Bobot Kering Biji. Hasil analisis sidik ragam menunjukkan bahwa pemberian kompos kulit buah kakao dan pupuk NPK tablet tidak berpengaruh nyata terhadap bobot basah biji dan bobot kering biji kakao. Bobot basah biji dan bobot kering biji kakao disajikan dalam Tabel 6.

Perlakuan pemberian kompos kulit buah kakao dan pupuk NPK tablet tidak memberikan pengaruh nyata. Hal ini diduga karena tingginya penyakit busuk buah yang disebabkan oleh serangan Phytoptora palmivora akibat curah hujan yang tinggi selama percobaan. Semakin tinggi tingkat penyakit busuk buah, bobot kering biji yang dihasilkan cenderung semakin kecil karena biji baik yang dihasilkan semakin sedikit sementara biji gepeng dan biji rusak yang ada semakin banyak (Djauhari dkk., 2013).

Walaupun secara statistik pemberian kompos kulit buah kakao tidak berpengaruh nyata namun pada Tabel 6 menunjukkan trend perlakuan pemberian kompos kulit buah kakao $9 \mathrm{~kg}$ dan pupuk NPK tablet 20 butir dan pemberian kompos kulit buah kakao $18 \mathrm{~kg}$ dan pupuk NPK tablet 10 butir cenderung mampu meningkatkan bobot basah biji kakao dan bobot kering biji kakao. Hasil Produksi produksi kering biji di PT PP Bajabang yang memiliki hasil biji kering $707 \mathrm{~kg} / \mathrm{ha} /$ tahun. Bobot kering biji apabila diasumsikan per hektar perlakuan pemberian kompos kulit buah kakao $9 \mathrm{~kg}$ + pupuk NPK tablet 20 butir dan perlakuan pemberian kompos kulit buah kakao $18 \mathrm{~kg}+$ pupuk NPK tablet 10 butir memiliki bobot kering biji $976 \mathrm{~kg} / \mathrm{ha}$ dan $824 \mathrm{~kg} / \mathrm{ha}$. Hal ini menunjukan bahwa pemberian pupuk kompos kulit buah kakao dan pupuk NPK cenderung meningkatkan bobot kering biji kakao. 
Penambahan kompos kulit buah kakao mampu memberikan unsur hara yang cukup yang dibutuhkan tanaman untuk mendukung perkembangan hasil kakao (Baihaqi dkk., 2015). Kompos kulit buah kakao mengandung C-organik sebesar 42,4\% dan N-total 3,57\%, $\mathrm{P}_{2} \mathrm{O}_{5} 1,25 \%, \mathrm{~K}_{2} \mathrm{O} 0,27 \%, \mathrm{CaO} 0,85 \%, \mathrm{MgO}$ $0,57 \%, \mathrm{~S} 0,79 \%$. Selain itu, pemberian pupuk NPK tablet juga turut menyubang kebutuhan unsur hara yang diperlukan tanaman kakao. Pupuk NPK tablet yang digunakan memiliki kandungan N $12 \%$ P $12 \%$ K $17 \%$.

Ketersediaan hara yang lebih baik tersebut ditengarai akan meningkatkan produksi biji. Haron (2003), menunjukkan adanya perbaikan status kimia tanah dan respons positif tanaman kelapa sawit terhadap aplikasi bahan organik. Hariyono dan Romli (2007), menyatakan bahwa pupuk NPK tablet memberikan pertumbuhan paling baik dan meningkatkan hasil jarak pagar. Selain karena perbaikan sifat kimia tanah, respons positif produksi kakao ditengarai juga disebabkan oleh perbaikan sifat tanah lainnya karena bahan organik yang diberikan juga dapat berpengaruh positif terhadap sifat fisik dan biologi tanah.

Tabel 6. Pengaruh Kompos Kulit Buah Kakao dan Pupuk NPK Tablet terhadap Bobot Basah Biji dan Bobot Kering Biji Kakao (Gram/Biji) pada 12 MSP

\begin{tabular}{ccc}
\hline Perlakuan & \multicolumn{2}{c}{ Waktu Pengamatan (12MSP) } \\
A & Bobot Basah Biji (g) & 34,67 \\
B & 86,67 & 34,80 \\
C & 87,00 & 34,67 \\
D & 86,67 & 36,80 \\
E & 92,00 & 37,73 \\
F & 94,33 & 40,80 \\
G & 102,00 & 39,20 \\
H & 98,00 & 39,20 \\
I & 98,00 & 39,87 \\
J & 99,67 & 40,67 \\
\hline
\end{tabular}

Keterangan :- -Angka yang tidak ditandai dengan huruf menyatakan tidak berbeda nyata menurut Uji F pada taraf kepercayaan $95 \%$.

\section{KESIMPULAN DAN SARAN}

\section{Kesimpulan}

Berdasarkan hasil percobaan yang telah dilakukan dapat disimpulkan bahwa:

1. Pemberian kompos kulit buah kakao dan pupuk NPK tablet berpengaruh nyata pada jumlah pentil layu pada 12 MSP dan bobot buah kakao, tetapi tidak berpengaruh nyata terhadap jumlah pentil terbentuk, jumlah pentil sehat, bobot basah biji dan bobot kering biji.

2. Pemberian kompos kulit buah kakao 9 $\mathrm{kg} /$ pohon + pupuk NPK tablet 20 butir dan kompos kulit buah kakao $18 \mathrm{~kg} /$ pohon + pupuk NPK tablet 10 butir mampu menekan presentase jumlah pentil kakao layu pada 12 MSP dan juga mampu meningkatkan bobot buah kakao.

\section{Saran}

Hasil percobaan terdapat dua kombinasi terbaik untuk menekan presentase jumlah pentil kakao layu dan meningkatkan bobot buah kakao, sehingga dianjurkan pemberian kompos kulit buah kakao 18 $\mathrm{kg} /$ pohon + pupuk NPK tablet 10 butir/pohon apabila dilihat dari segi efisiensi penggunaan 
50 IPaspalum: Jurnal IImiah Pertanian Vol.6, No.1, Maret

2018

pupuk. Selain itu diharapkan terdapat penelitian lanjutan mengenai penggunaan ZPT terhadap hasil tanaman kakao.

\section{DAFTAR PUSTAKA}

Abdurachman, A. A. Dariah, dan A. Mulyani. 2008. Strategi dan Teknologi Pengelolaan Lahan Kering Mendukung Pengadaan Pangan Nasional. Jurnal Litbang Pertanian 27(2):43-49.

Ahmad, F. 2015. Aplikasi Air Kelapa dan Unsur Hara Zn Untuk Mengatasi Layu Pentil (Cherelle Wilt) pada Tanaman Kakao (Theobroma cacao L.) dengan Teknik Penyemprotan Buah. Skripsi. Jember: Fakultas Pertanian Universitas Jember.

Atmadja, W Rahmat. 2012. Pengendalian Helopeltis Secara Terpadu Pada Tanaman Perkebunan. Bogor. Unit Penerbitan dan Publikasi Balitro.

Azri. 2015. Pengaruh Pemupukan terhadap Pertumbuhan dan Buah Tanaman Kakao. Jurnal Agros Vol.17 No.2.

Baihaqi, A., H. Hamid, A. Anhar, Y. Abubakar, T. Anwar, dan Y. Zanuzar. 2015. Penerapan Teknik Budidaya serta Hubungan antara Pemangkasan dan Peningkatan Kesuburan Tanah terhadap Peningkatan Produktivitas Kakao di Kabupaten Pidie. Agrisep Vol (16) No. 2, 2015.

Baon, J. B. dan A. Wibawa 2005. Kandungan bahan organik dan lengas tanah serta produksi kopi pada budi daya ganda dengan tanaman sumber bahan organik. Pelita Perkebunan. Volume 21. Hal 4354.

Bidang Pasca Panen dan Sistem Informasi Dinas Perkebunan Sulawesi. 2010. Kakao. Hal 7-8.

Darjanto dan S. Satifah. 1982. Biologi Bunga dan Teknik Penyerbukan Silang Buatan. Jakarta: Penerbit PT Gramedia.

Darmono dan T. Panji. 1999. Penyediaan kompos kulit buah kakao bebas Phytophthora palmivora. Warta Penelitian Perkebunan. V(1):33-38.
Direktorat Jenderal Perkebunan. 2014. Produksi Kakao Menurut Provinsi di Indonesia, 2008 - 2012. Kementrian Pertanian Republik Indonesia.

Djauhari, A., A. M. Hasibuan, dan Rubiyo. 2013. Pengaruh Teknologi Fermentasi terhadap Peningkatan Kualitas Biji dan Pendapatan Petani Kakao. Bogor. Hal 257-264.

Erwiyono, R. A., A. Sucahyo, Suyono, dan S. Winarso. 2006. Keefektifan Pemupukan Kalium Lewat Daun Terhadap Pembungaan dan Pembuahan Tanaman Kakao. Pelita Perkebunan ISSN 02150212 (2006). Hal 30-36.

Food Association Organization. 2014. Cacao Production by Country.

Gomez, K. A., dan A. A. Gomez. 1995. Prosedur Statistik untuk Penelitian Pertanian Terjemahan dari Statistical Procedures for Agricultural Research. Terjemahan E. Sjamsuddin dan J.S. Baharsjah. Universitas Indonesia Press, Jakarta. Edisi Kedua.

Hardjowigeno, S. 2003. Ilmu Tanah. Akademika Pressindo, Jakarta.

Hartati, R M., A. Prawoto., K. Dewi., dan Y. Astuti. 2007. Analisis Hubungan Antara Hormon Auksin, Giberelin, dan Sitokinin pada Perkembangan Buah Kakao dalam Mengatasi Layu Buah Muda Kakao (Theobroma cacao L.). Ringkasan Eksekutif Hasil-Hasil Penelitian Tahun 2007. Hal 20-29

Haron, K. 2003. Inorganic and organic fertilizers combined for efficient use of fertilizers in oil palm. Proceeding of Agriculture Conference PIPOC, Putrajaya, 167-180.

Hariyono, B., dan Romli M. 2007. Pengaruh Pemupukan NPK tablet Terhadap Pertumbuhan Dan Hasil Jarak Pagar (Jatropha curcas 1.) tahun kedua. Hal 55 .

Karmawati, E. Z. Mahmud., M. Syakir., J .S. Munarso., I K Ardana., dan Rubiyo.2010. Budidaya dan Pasca Panen Kakao. Pusat Penelitian dan Pengembangan Perkebunan. Bogor Hal 20-68 
51 I Paspalum: Jurnal IImiah Pertanian Vol.6, No.1, Maret

2018

Khasanah, M. N. 2012. Pengaruh Pupuk NPK Tablet dan Pupuk Nutrisi Organik Cair terhadap Pertumbuhan Bibit Kelapa Sawit (Elaeis guineensis $J$ ) di Pembibitan Utama.

Liferdi, R. Poerwanto, dan L. K. Darusman. 2005. Perubahan Kandungan Karbohidrat dan Nitrogen 4 Varietas Rambutan. Jurnal Hort 16(2): 134-141. 2005.

Lingga, P dan Marsono. 2008. Petunjuk Penggunaan Pupuk. Jakarta. Penebar Swadaya. hlm 8 .

Megawati, M. dan H. Umar. 2015. Pengaruh Berbagai Perbandingan Pupuk Organik Limbah Kulit Kakao (Theobroma Cacao. L) terhadap Pertumbuhan Semai Jati (Tectona Grandis L. F). Warta Rimba Volume 3 Nomor 2.

McKelvie A.D. 1956. Cherelle Wilt of Cacao. I. Pod Development and Its Realition to Wilt. J. Expp. Bot. 7(20):250-263.

Nichols, R. 1965. Studies of Fruit Development of Cacao (Theobroma cacao L.) in Relation to Cherelle Wilt. I. Development of the pericarp. Ann. Bot. N. S., 28(112): 619-635

Nur, A.M. dan A. Wibawa. 1994. Pengaruh hujan terhadap pembuahan kopi Robusta, kasus penurunan hasil tahun panen 1993 di Jawa Timur. Pelita Perkebunan. 9(4),172-178.

Nurdin. 2012. Morfologi, Sifat Fisik dan Kimia Tanah Inceptisol dari Bahan Lakustrin Paguyaman Gorontalo kaitannya dengan Pengelolaan Tanah. JATT Vol. 1 No. 1. April 2013. 13-22.

PT. PP. Bajabang Indonesia. 2016. Rekomendasi Penggunaan Pupuk N P dan K pada Blok Cilimus. Bandung.

Pratama, S W., S. Sukamto, I. N. Asyiah dan Y. V. Ervina. Penghambatan Pertumbuhan Jamur Patogen Kakao Phytophtora Palmiovora oleh Pseoudomonas flourscence dan Bacillus Subtillis. Pelita Perkebunan. 120-127.

Prawoto, A A. 2014. Dinamika Pertunasan, Layu Pentil, dan Ketepatan Taksasi Produksi Beberapa Klon Kakao. Pelita Perkebunan. Hal 100-114
Priyatno, E. 2015. Hama dan Penyakit Tanaman Kakao ( Theobroma cacao L.). Bantul.

Pusat Penelitian Kopi dan Kakao. 1997. Laporan Semester II Pengujian Pupuk Suburin Pada Tanaman Kopi dan Kakao. PT Sari Bumi Dewata Lestari. Bandung.

Pusat Penelitian Kopi dan Kakao Indonesia. 2004. Panduan Lengkap Budidaya Kakao. PT Agromedia Pustaka. Jakarta. Hlm 12-23.

Pusat Penelitian Kopi dan Kakao. 2010. Budidaya Kakao. Agro Media Pustaka. Jakarta. Hlm 29.

Puslitbang Perkebunan. 2010. Budidaya dan Pasca Panen Kakao. Bogor. Hlm 21.

Rakasiwi, R. A. Edison., dan M. Gulat M E. 2014. Pengaruh Pupuk Kompos Limbah Sayur dan Pupuk NPK Tablet terhadap Pertumbuhan dan Produksi Jagung Manis (Zea mays L. Var. saccharata Sturt). Jom Faperta Vol. 1 No. 2 Oktober 2014.

Rosniawaty, S. I. R. D. Anjasari, dan C. Suherman. 2005. Pemanfaatan Kulit Buah Kakao sebagai Kompos Pada pertumbuhan bibit kakao (Theobroma cacao L.) Kultivar upper amazone hybrid. Laporan penelitian, jurusan budidaya pertanian, faperta, unpad. Bandung.

Santoso, B.; A. Sastrosupadi dan Djumali. 2003. Pemanfaatan Blotong dan Fosfat Alam Pada Tanaman Rosela di Lahan Podsolik Merah Kuning Kalimantan Selatan. Jurnal Littri., 9, 109-116

Salisbury, Frank B dan Cleon W Ross. 1995. Fisiologi Tumbuhan jilid 2. ITB. Bandung.

Sarief, E.S. 1986. Kesuburan dan Pemupukan Tanah Pertanian. Pustaka Buana, Bandung.

Schmidt, F.H., and J.H.A. Ferguson. 1951. Rainfall type based on wet and dry period ratio for Indonesia with Western New Guinea. Kementerian Perhubungan. Jawa-tan Meteorologi dan Geofisika. Jakarta

Sudirja, R. S, M. Amir, dan S, Rosniawaty. 2005. Pengaruh Kompos Kulit Buah 
Kakao Dan Kascing terhadap Perbaikan Beberapa Sifat Kimia Fluventic Eutrudepts. Laporan Penelitian.

Sugiyanto. J. B. Baon., dan K. A. Wijaya. 2008. Sifat Kimia Tanah dan Serapan Hara Tanaman Kakao Akibat Bahan Organik dan Pupuk Fosfat yang Berbeda. 2008. Pelita Perkebunan 24(3), $188-204$.

Sutanto, R. 2002. Penerapan Pertanian Organik (Pemasyarakatan dan Pengembangannya). Kanisius Yogyakarta.

Sutejo, M. 2002. Pupuk dan Cara Pemupukan. Rineka Cipta, Jakarta.

Stevenson, F.J. 1994. Humus Chemistry. Genesis, Composition, Reaction. 2nd ed. John Wiley and Sons. New York.

Wahab, Abdul. 2007. Pengenalan dan Pengendalian Penyakit Busuk Buah Kakao (Phytophtora palmipora).

Wahyudi, T. Panggabean T. R., dan Pujiyanto. 2008. Panduan Lengkap Kakao Menejemen Agribisnis Dari Hulu Hingga Hilir. Penebar Swadaya. Jakarta Hal 10-25.

Wahyudi, Imam. 2010. Kajian Perubahan Status Fosfor Tanah Akibat Pemberian Kulit Buah Kakao Pada Inceptisols Palolo. J. Agroland 17 (2) : 131-137.

Widiancas A. P. 2010. Aplikasi ZPT NAA dan Unsur Mikro Mengatasi Layu Pentil (Cherelle wilt) pada Kakao (Theobroma cacao L.) dengan Tehnik Penyemprotan Buah. [Skripsi].Fakultas Pertanian Universitas Sebelas Maret, Surakarta. 
